\title{
The effect of late autumn cutting of lucerne (Medicago sativa L.) on the growth rhythm of the first cut in the following year
}

\author{
Miran PODVRŠNIK, Anastazija GSELMAN \\ University of Maribor, Faculty of Agriculture and Life Sciences, Pivola 10, 2311 Hoče, Slovenia
}

\begin{abstract}
The field experiment aimed at determination of influence of autumn harvest on rhythm of the growth of lucerne (Medicago sativa L.) and yield quality of the first cut in the following year was carried out in Spodnji Gabernik (258 $\mathrm{m}$ above sea level, $46^{\circ} 15^{\prime} 54.94^{\prime \prime} \mathrm{N}$ and $15^{\circ} 34^{\prime} 6.05^{\prime \prime} \mathrm{E}$ ), in the fourth growth year of the lucerne variety 'Soča'. The experiment was designed as a randomized block in four replications. The individual treatments represented weekly autumn cuttings (1) 24/9/2014, (2) 01/10/2014, (3) 08/10/2014, (4) 15/10/2014 and (5) 22/10/2014. The paper presents data associated with the amount of lucerne dry matter yield (DMY) per treatment compared with the DMY of the first spring cut in the year 2015 (18/05/2015). The growth rhythm of lucerne in each treatment, which took place before the first cut in year 2015, was based on the measurements of the height of the plants. The yield quality was evaluated by NIRS method for determination of crude protein (CP), the net energy of lactation (NEL) and metabolic energy (ME) in dry samples regarding to DMY of each treatment. In autumn 2014, statistically significant higher dry matter yields were obtained in later harvested treatments (5 and 4). Similarly, in spring 2015 the trend of higher crop dry matter yield was observed in treatments harvested later in the autumn of 2014. However, the differences were not significant. Statistically significant differences between treatments were acquired within CPY, NELY and MEY. Before the first mowing, in spring 2015, statistically significant trend of higher plants was also detected in treatments with later cutting in 2014.
\end{abstract}

Key words: lucerne, Medicago sativa, cutting regime, growth rhythm, dry matter yield

\section{INTRODUCTION}

Production of high quality forage which represents the main fodder for cattle, and consequently, reduces the use of more expensive purchased concentrates, is a strong challenge for the majority of Slovenian breeders. In last few decades, lucerne (Medicago sativa L.) has become more frequently present in the field rotation, mainly due to more frequent periods of drought during the growing season.

Lucerne is one of the oldest known forage crops on arable land (Kramberger 1995). It belongs to the legume plant family (Fabaceae). The most important benefits of the legumes are that they can satisfy their nitrogen requirements through a symbiotic association with Rhizobium sp. (and other related genera) bacteria. Estimates of quantities of N2 fixation by lucerne vary widely but, on annual basis, are generally higher on than those of other temperate forage legumes (Witty et al. 1983, Heichel and Henjum 1991).
In 2014, lucerne was planted on 3421 ha of arable land in Slovenia, which was 3.4 times more in comparison with 2004 (Statistical Office of the Republic of Slovenia 2015). Amongst the main reasons for the increased presence of lucerne in arable land was more frequent occurrence of dry summers in the above mentioned period. Lucerne develops a deep root system and thereby tolerates drought better (Small 2011). The strong tap root in the first year usually reaches 1 to $2 \mathrm{~m}$ in depth but in the following years of growth root penetration can be deeper than 4 to $5 \mathrm{~m}$ (Frame et al. 1998). Concerning the weight, most of lucerne roots are spread to the depth of $30 \mathrm{~cm}$. More frequent use as cutting or rotational grazing is weakening the growth of the root system (Kramberger 1995, Korošec 1998).

For lucerne production, the term of the first cut in spring is extremely important because early cut adversely affects the vitality of plants, causes weakening of the root system development, and shortens the period of crop exploitation

${ }^{*}$ Correspondence to:

E-mail:anastazija.gselman@um.si 
(Sheaffer et al. 1986). However, late spring mowing provides higher yields but of lower forage quality and lower voluntary intake by animals. At least 35 days should elapse between individual mowings, so that plants in the mean time could synthesize sufficient reserves for the regeneration and nutrition of roots. Between the last mowing of lucerne in the season and occurrence of the first cold, a recovery period of 30 to 50 days is needed (Sheaffer et al. 1986, Katić 2003, Međimurec 2007). It enables a successful development of the vegetation in the following year. In addition, increased cutting frequency and very late autumn harvesting may have a negative impact on lucerne longevity (Small 2011).

Concerning the intensity of exploitation, lucerne is a perennial plant species with its own characteristics which affect its development and yield. It grows better in temperate and relatively dry climate. The growth of lucerne is highly dependent on heat. The optimum air temperature for growth is between 10 and $25^{\circ} \mathrm{C}$, and depends of stage of plant development and re-growth. Although lucerne is well adapted to extremely high temperatures, temperatures higher than $35^{\circ} \mathrm{C}$ may cause heat injuries (Major et al. 1991, Kendall et al. 1994). For intensive plant growth and development, a sum of active temperatures from 700 to $900{ }^{\circ} \mathrm{C}$ is required up to flowering. To produce high yield, plants must be able to uptake enough water since transpiration coefficient ranges between 700 and 830 litres (Korošec 1998).

Lucerne is most frequently used as a forage plant providing forage of excellent quality. Generally, it is grown in monostands, although it can be mixed with some other legumes or grasses. The production capacity of lucerne is very high. Without nitrogen fertilization, it can produce higher quantity of digestible proteins per hectare than any other crop (Kramberger 1995). Lucerne has a lower cell-wall constituents and digestible fibers, but higher cell contents, crude protein and lignin content as grasses at similar stages of growth (Frame et al. 1998).

The objective of the present study was to investigate the timing of the last autumn cut on the average dry matter yield and to assess its impact on development of lucerne in the following year. Furthermore, the objective of the study was to investigate the effect of autumn cutting regime on crude protein content, net energy for lactation and metabolizable energy yields provided by the last autumn and the first spring cut in the following year.

\section{MATERIAL AND METHODS}

\section{The trial site}

The field experiment was established in autumn 2014, in the fourth growth season of the lucerne variety 'Soča', on the Strašek farm in Spodnji Gabernik (258 m above sea level, $46^{\circ} 15^{\prime} 54.94^{\prime \prime} \mathrm{N}$ and $15^{\circ} 34^{\prime} 6.05^{\prime \prime} \mathrm{E}$ ). The experiment was designed as a randomized block involving five treatments in four replications. The size of each plot was 19.2 square meters. The last summer harvesting was carried out on August $30^{\text {th }} 2014$. The individual treatments were based on times of autumn cutting, and were as follows:
Treatment 1 - performed 25 days after last summer harvesting, $24^{\text {th }}$ September,

Treatment 2 - performed 32 days after last summer harvesting, $1^{\text {st }}$ October,

Treatment 3 - performed 39 days after last summer harvesting, $8^{\text {th }}$ October,

Treatment 4 - performed 46 days after last summer harvesting, $15^{\text {th }}$ October,

Treatment 5 - performed 53 days after last summer harvesting, $22^{\text {nd }}$ October.

In spring 2015, the first cutting in all treatments was performed at the same time (May 18 $8^{\text {th }} 2015$ ).

\section{Measurements}

For estimating the aboveground biomass, dry matter yield and nutrient content (crude protein and the net energy of lactation), the sward of each plot was cut at several points (50 $\mathrm{cm} \times 50 \mathrm{~cm}$ ) to a stubble height of about 7 to $8 \mathrm{~cm}$, and weighed. The forage samples were dried at 50 to $55^{\circ} \mathrm{C}$ in air-forced oven to a constant mass for approximately 48 hours. Before the first spring mowing, measuring of height of 10 plants at seven different time intervals took place on each plot (March $28^{\text {th }}$; April $6^{\text {th }}, 12^{\text {th }} 23^{\text {rd }}$ and $29^{\text {th }}$; May $5^{\text {th }}$ and $18^{\text {th }}$.

For the assessment of the nutritional value of the aboveground lucerne samples, the method of measuring the reflectance of near-infrared light (NIRS) was used. The spectra of air-dried and milled samples $(1 \mathrm{~mm})$ were recorded by using NIR-analyzer (Foss NIRSystem 6500 Monochromator) and software (WinISI II Version 1.5) at the wavelength range of 400-2500 nm. Hygroscopic bound water, content of crude protein $(\mathrm{CP})$, crude fibre, NDF, $\mathrm{ADF}$, ash, crude fat and volume of gas generated during the incubation of lucerne samples with rumen liquor "in vitro" was estimated on the basis of spectra and general calibration equation for meadow forage. The calibration equation in addition to the preserved samples from sown grasses and natural grasslands (green fodder, hay and grass silage) was also included in various preserved lucerne samples. The content of metabolic energy (ME) and net energy for lactation (NEL) were calculated using German regression equation (GfE 2008) based on the data of the chemical composition and volume of gas in samples.

The composition and the nutritional value of sampled material were determined at the Agricultural Institute of Slovenia.

\section{Weather conditions}

Monthly sum of precipitations (Figure 1) and the average monthly temperatures (Figure 2) indicate that the autumn of 2014, at the site of meteorological station Gabernik near Rogaška Slatina (379 m above sea level, 100 meters from the site of the experiment) was wetter and warmer than the longterm average achieved in the meteorological station of Rogaška Slatina. 


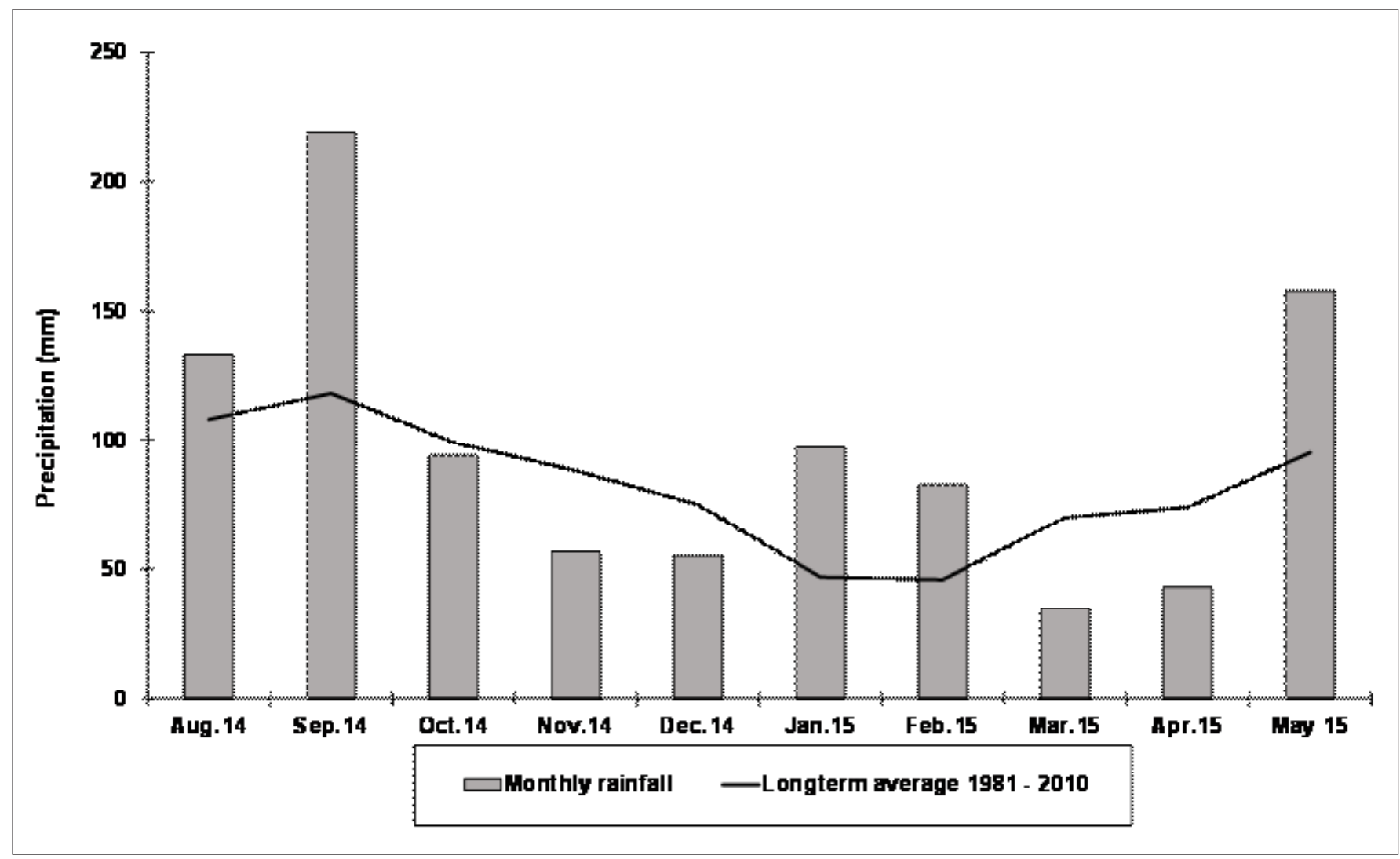

Fig. 1: Monthly amount of precipitation $(\mathrm{mm})$ for Gabernik compared with the longterm average of Rogaška Slatina (Agrometeorological portal of Slovenia 2015, National Meteorological Service 2015).

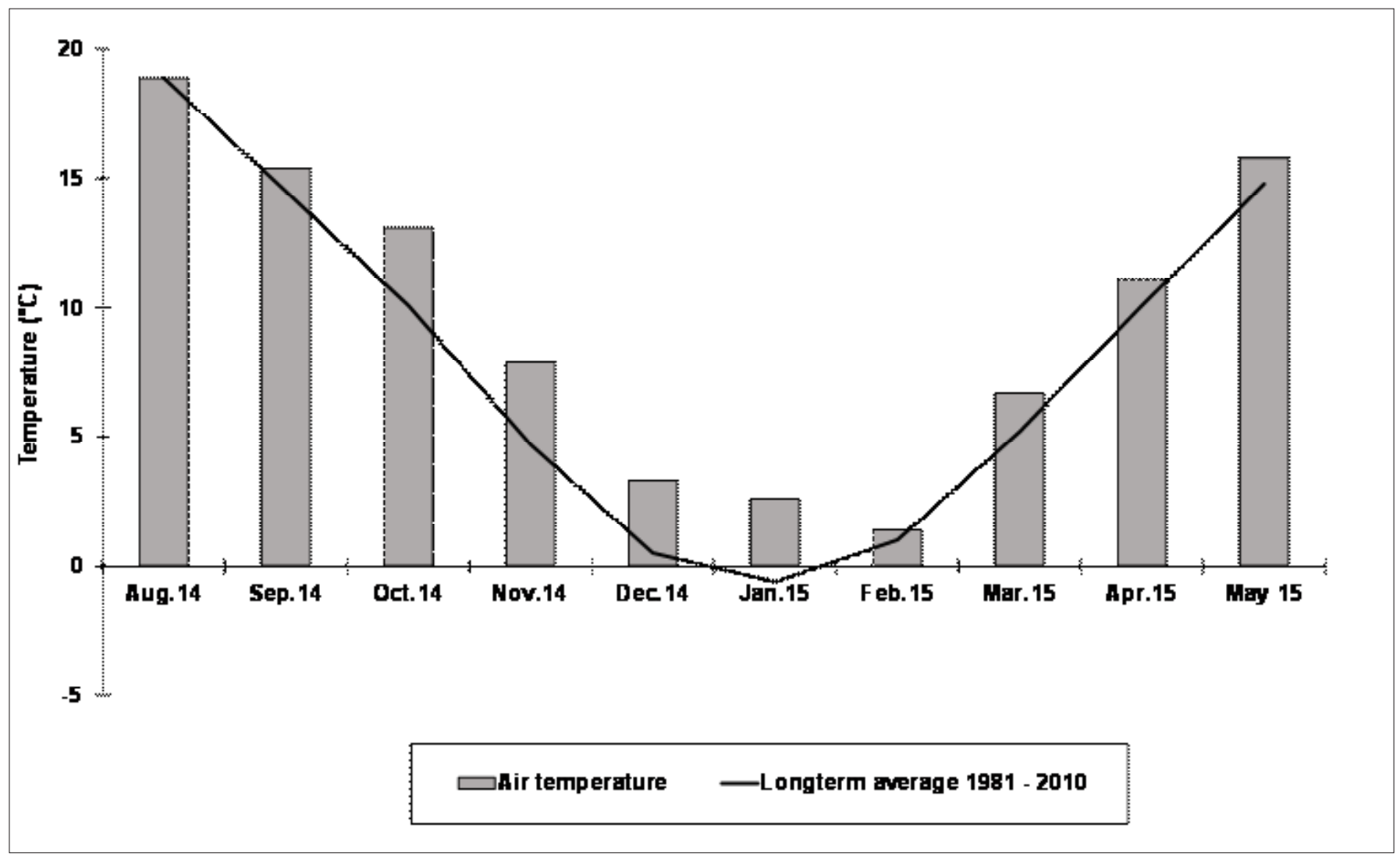

Fig. 2: Average air (at $2 \mathrm{~m}$ ) temperature $\left({ }^{\circ} \mathrm{C}\right)$ for Gabernik compared with longterm average for Rogaška Slatina (Agrometeorological portal of Slovenia 2015, National Meteorological Service 2015). 


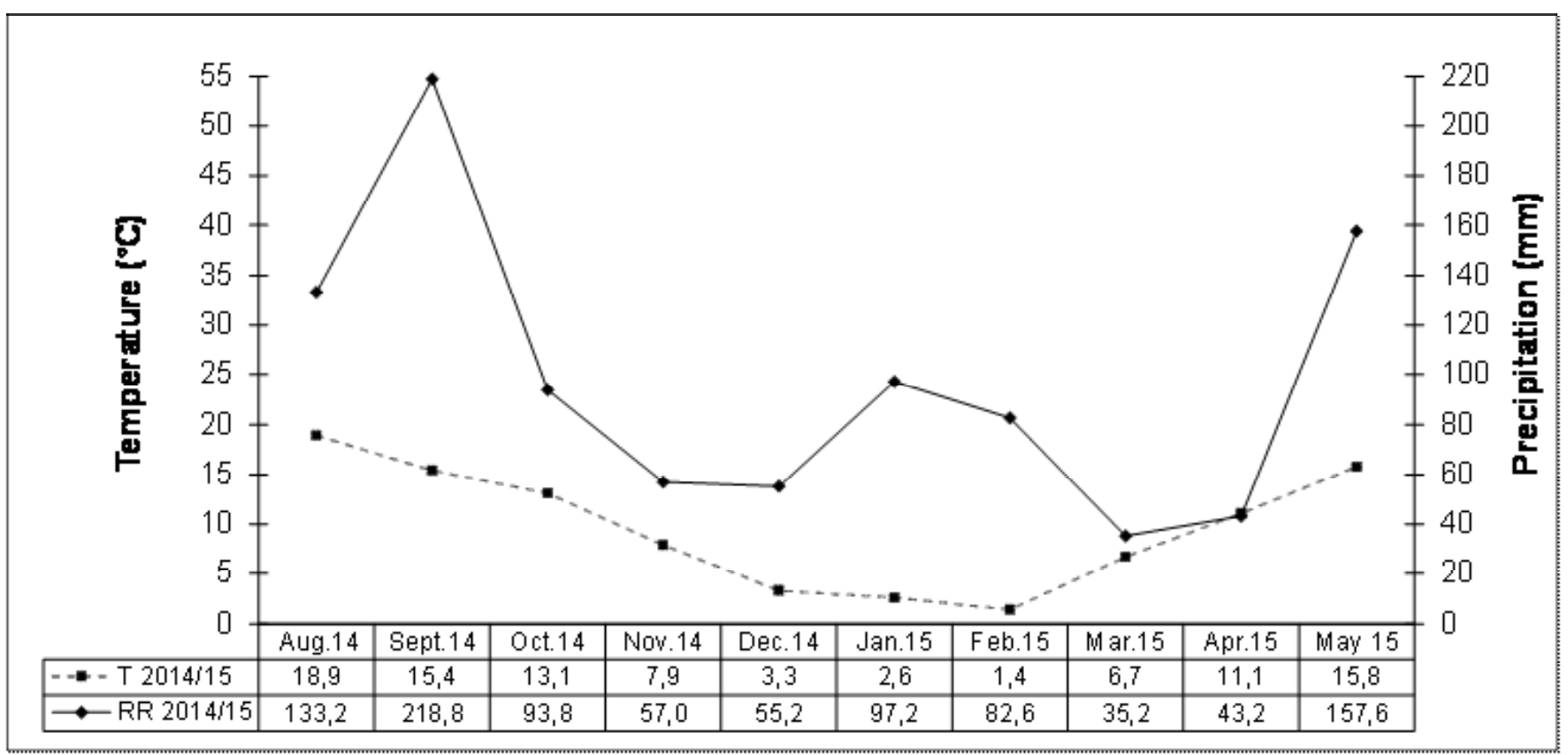

Fig. 3: Relationship between temperature and precipitation (1 to 4) for Gabernik during the experiment (Agrometeorological portal of Slovenia 2015, National Meteorological Service 2015).

At the beginning of the growing season, in March and April of 2015, slightly less rainfall was recorded than the long-term average of Rogaška Slatina, while the average temperature was $1{ }^{\circ} \mathrm{C}$ higher. Extremely humid period was recorded in May 2015 when the amount of precipitation exceeded the long-term average by $65 \%$.

During the experiment, there was no drought, which is evident from the Figure 3.

\section{Statistical analyses}

Statistical analyses were performed by using the statistical program Statgraphics Centurion XV Professional statistical package (Statgraphics 2005). The analysis of variance (ANOVA) was performed for plant height before the first mowing in 2015, for the aboveground biomass dry matter yield (DMY; kg ha-1), crude protein yield (CPY; kg ha ${ }^{-1}$ ),

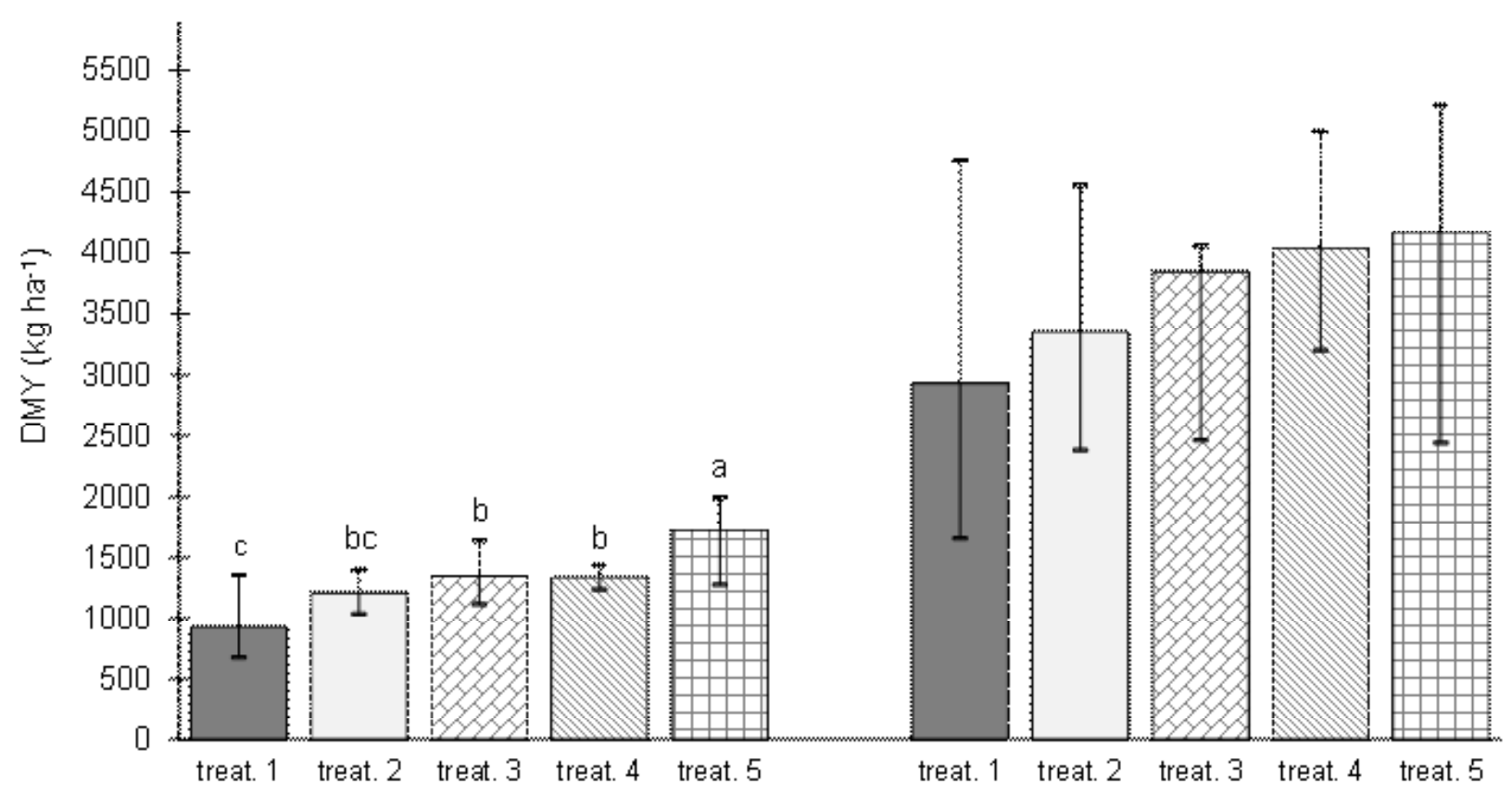

Autumn 2014

Spring 2015

Fig. 4: The effect of the period of harvesting on the dry matter yield (DMY) of lucerne in autumn 2014 and in spring 2015. Means followed bydifferent letter within a treatment significantly differ (LSD, $p \leq 0.05)$. Bars show standard errors. 
the net energy for lactation yield (NELY; GJ ha $\mathrm{h}^{-1}$ ) and the metabolisable energy yield (MEY; GJ ha ${ }^{-1}$ ) of the last cut in 2014 and the first cut in 2015. Significances of differences between means at $\mathrm{P} \leq 0.05$ were tested using the LSD method.

\section{RESULTS AND DISSCUSION}

\section{Dry matter yield}

In autumn 2014, the average aboveground biomass DMY significantly differed amongst treatments. The differences were expected since DMY depends on the length of the growing period, which ranged from 25 to 53 days. The highest DMY (1730 kg ha ${ }^{-1}$ ) was obtained in the treatment where, after the latest cut, lucerne continued to grow for 53 days (Figure 4), and the lowest in treatments 1 and 2 where lucerne, after the last summer cut, continued to grow for 25 and 32 days (930 $\mathrm{kg} \mathrm{ha}^{-1}$ and $1210 \mathrm{~kg} \mathrm{ha}^{-1}$, respectively). The presumption of the experiment was that the differences in plant height among the treatments before winter season would cause significant differences amongst treatments in dry matter yield of the first cut in 2015. As is shown in Figure 4, trend of higher DMY was observed in treatments harvested later in autumn 2014. However, the differences were not significant. Corresponding dry matter yields ranged from $4175 \mathrm{~kg} \mathrm{ha}^{-1}$ (treatment 5) to $2930 \mathrm{~kg} \mathrm{ha}^{-1}$ (treatment 1), respectively.

Study of lucerne DMY by Katić et al. (2007) showed that the average DMY ranged from 13.9 to 16.1 t DMY per hectare.
In our case, the DMY yield of the first spring cut of lucerne corresponded to $29.9 \%$ (treatment 5 ) of the expected annual yield (14 $\mathrm{t} \mathrm{DMY} \mathrm{ha}^{-1}$ ). The results are in full accordance with Genever and McConnell (2014) which reported, that the DMY of first spring cut was within 30 to $35 \%$ of the total annual dry matter yield. The same authors indicate that the yield of the last cut in year represents $10 \%$ of the total annual yield ( 1000 to $2000 \mathrm{~kg}$ DM per hectare). The presented results of DMY of the last mowing in 2014 (treatment $5-12 \%$ ), which took place right after the settings of the experiment, are also comparable with the results of the authors mentioned before.

As reported by Barnes and Sheaffer (1995) and Small (2011), the dry matter yield of the first harvest in spring depends on the length of the interval between the last mowing and occurrence of the first frost in the season. However, in case of our experiment, DM yields of the first mowing in spring 2015 (treatment 5; 66 days elapsed from last harvest until the first frost $\left(27^{\text {th }}\right.$ of December 2014)) are similar to those obtained by authors mentioned above. The results of our experiment confirm the fact that lucerne requires for regeneration and successful overwintering 30 to 50 days for regrowth from the last harvesttill the occurrence of the first frost.

\section{CP, NEL and ME yields}

Based on DMY and results of NIRS analysis of feed samples CPY, NELY and MEY were calculated. Results for the first mowing in 2015 showed significant differences among the treatments. As shown in Figure 5, the highest CPY value was obtained

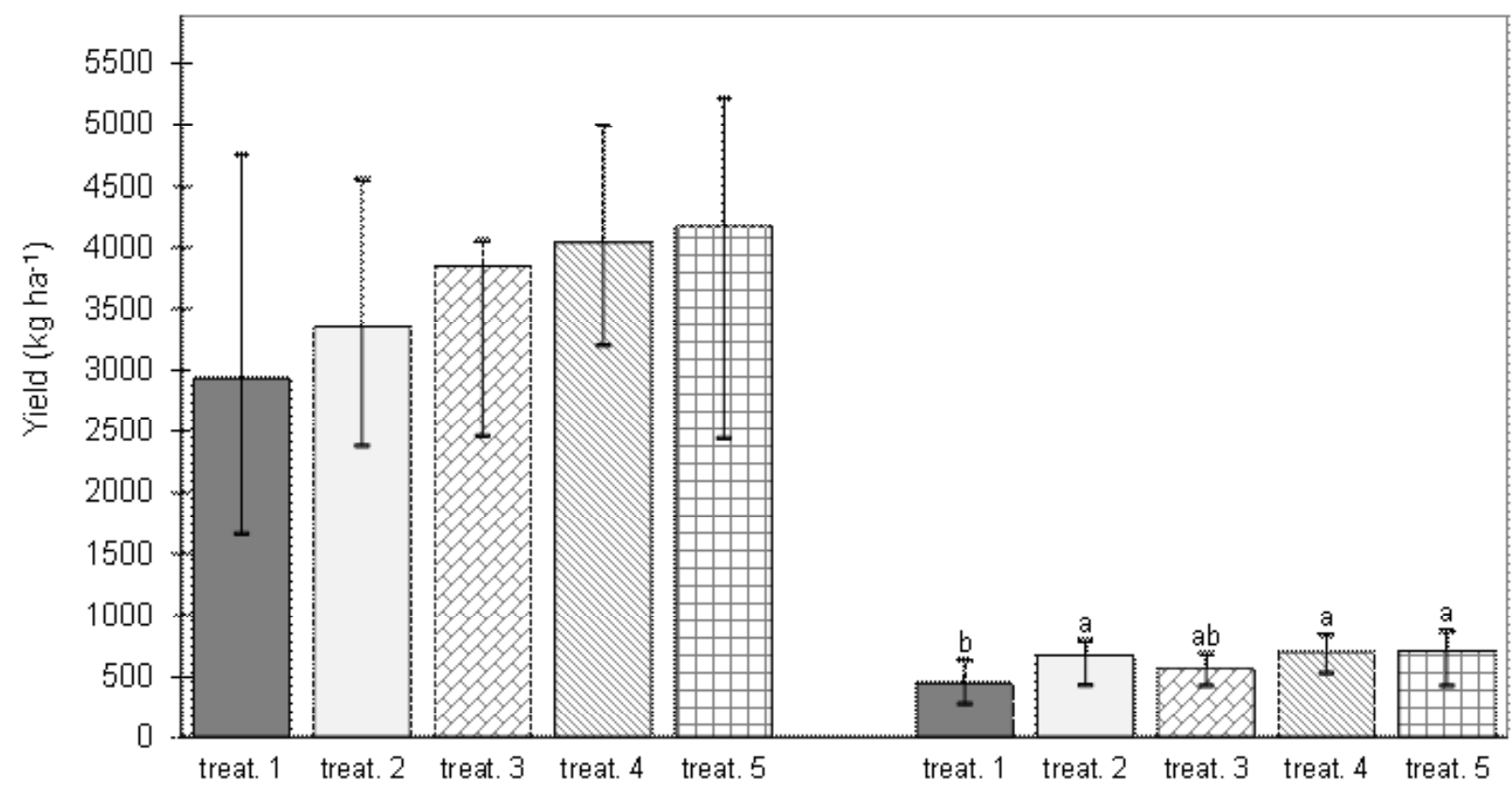

DM

$\mathrm{CP}$

Fig. 5: Amounth of dry matter and crude protein content in the lucerne yield of the first mowing in 2015. Means followed by different letter within a treatment significantly differ $(\mathrm{LSD}, \mathrm{p} \leq \mathbf{0 . 0 5})$. Bars show standard errors. 
in treatment $5\left(707.6 \mathrm{~kg} \mathrm{ha}^{-1}\right)$, while the lowest in treatment 1 (446.2 $\left.\mathrm{kg} \mathrm{ha}^{-1}\right)$. Statistical differences in CPY between treatments were mainly due to differences in DMY. However, the content of CP (g per $\mathrm{kg} \mathrm{DM}$ ) in individual samples of treatments were comparable and ranged from $172.5 \mathrm{~g}$ (treatment 4) to $167.3 \mathrm{~g}$ (treatment 1 ), respectively.

Similarly, the significant higher NELY and MEY were observed in treatments harvested later in autumn 2014 (Figure 6). The highest NELY value (22.2 GJ ha-1) as well as highest MEY value (37.9 $\mathrm{GJ} \mathrm{ha}^{-1}$ ) was obtained in treatment 5. The lowest value of NELY (13.9 GJ ha-1) and MEY (23.9 GJ $\mathrm{ha}^{-1}$ ) were determined in treatment 1 . Especially, statistical differences in the NELY and MEY among treatments were caused by differences among DMY. It is also evident that statistical differences in the NELY and MEY among treatments resulted from differences among DMY since the contents of NEL and ME were comparable. The calculated NEL content (MJ per $\mathrm{kg} \mathrm{DM}$ ) was between 5.2 MJ (treatment 1) and 5.4 MJ (treatment 3), and ME (MJ per kg DM) between 8.9 MJ (treatment 1) to $9.2 \mathrm{MJ}$ (treatment 3 ), respectively.

The hypothesis that quality of the forage in the first cut strongly depends on the latest autumn harvest of the previous year was confirmed. As observed by Steinhöfel and Hoffmann (2013) the yield of $6 \mathrm{t} \mathrm{DM} \mathrm{ha}^{-1}$ of the first cut in the season contained $1002 \mathrm{~kg}$ of CP ha-1, which was the content of 167 g CP per kilogram DM. Following their observation, some samples of lucerne contained $180 \mathrm{~g} \mathrm{CP}$ and 5.4 MJ NEL per kilogram of dry matter at the optimal harvesting time (from the forming the flower buds till the beginning of flowering). For the nutritional value of the crop, very important were time of cutting and cutting plant height. However, both parameters strongly depend on the stage of development of young shoots. Consequently, cutting height must not reach the axillary buds, originating in the axils of stems, which is closely associated with regrowth.

\section{Plant height}

Sequential measurements of plant height during the spring growth and significance among treatments are present in Figure 7 . The results of the first spring measurement indicated that spring growth might have been stimulated by the late autumn harvesting in the previous season. The highest plants were obtained in treatments 5 and 4 (harvesting performed $22^{\text {nd }}$ and $15^{\text {th }}$ of October $-8.3 \mathrm{~cm}$ and $7.8 \mathrm{~cm}$, respectively) and were significantly higher when compared with the remaining three treatments. In contrary, the differences amongst the earlier cut treatments $\left(24^{\text {th }}\right.$ of September, $1^{\text {st }}$ and $8^{\text {th }}$ of October, $-7.1 \mathrm{~cm}, 7.1 \mathrm{~cm}$ and $7.2 \mathrm{~cm}$, respectively) were insignificant.

Statistically significant differences in plant height among the treatments increased with stage of lucerne growth. The maximum plant height was established in the fourth measurement, in treatment $5(37.9 \mathrm{~cm})$ which was significantly higher than in all other treatments. The lowest plants were determined in treatment $1(30.0 \mathrm{~cm})$. However, treatments 1 and 2, 3 and 4 did not significantly differ to each other.

The last measurements took place just before the mowing of lucerne. Once again, the highest plants were recorded in treatment $5(93.2 \mathrm{~cm})$. Statistically significant differences were not detected between treatments 1 and 2 and between

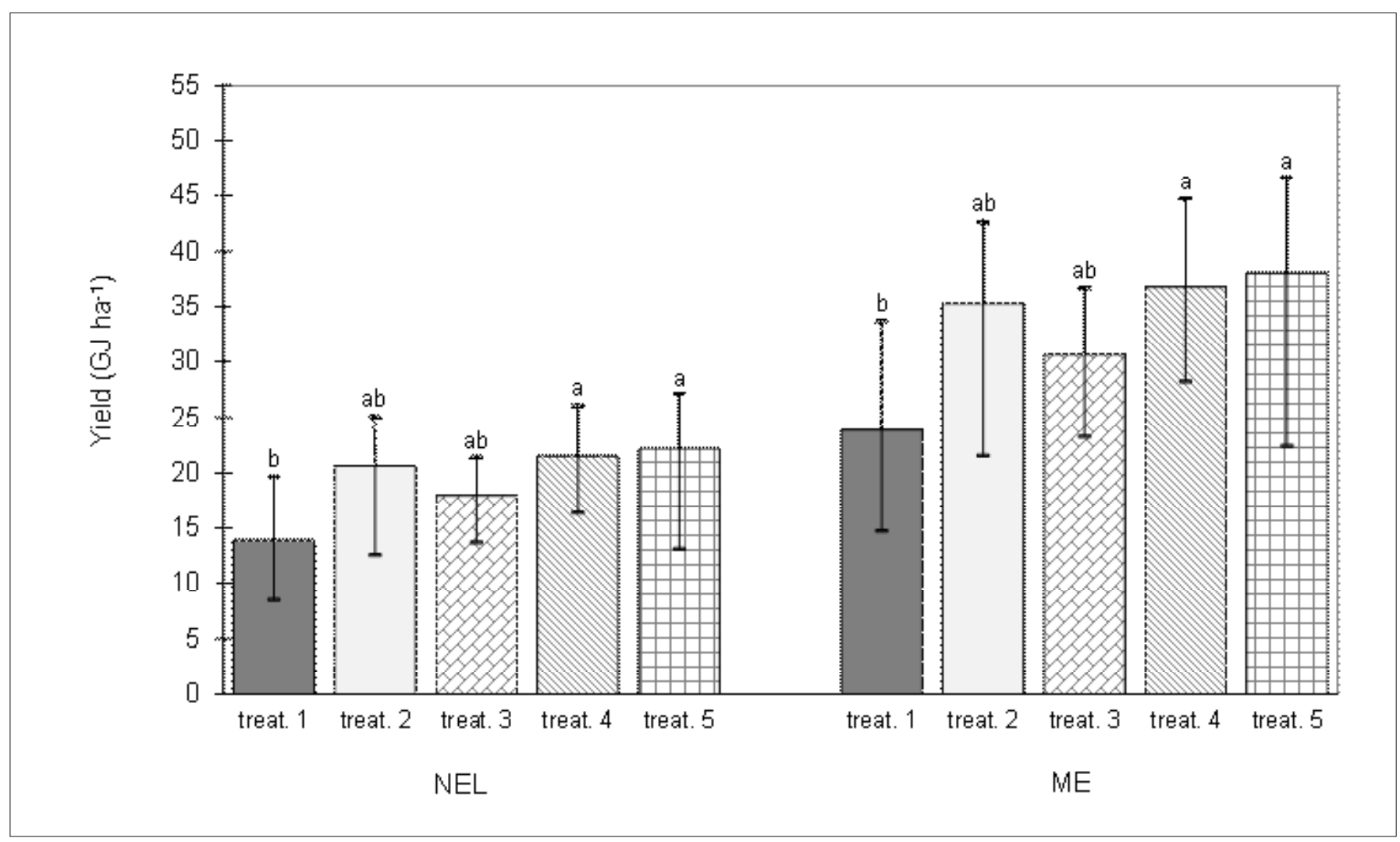

Fig. 6: Content of NEL (GJ ha $\left.{ }^{-1}\right)$ and ME (GJ ha $\left.{ }^{-1}\right)$ in the DMY among the treatments of the first mowing in 2015. Means followed bydifferent letter within a treatment significantly differ (LSD, $\mathrm{p} \leq \mathbf{0 . 0 5})$. Bars show standard errors. 


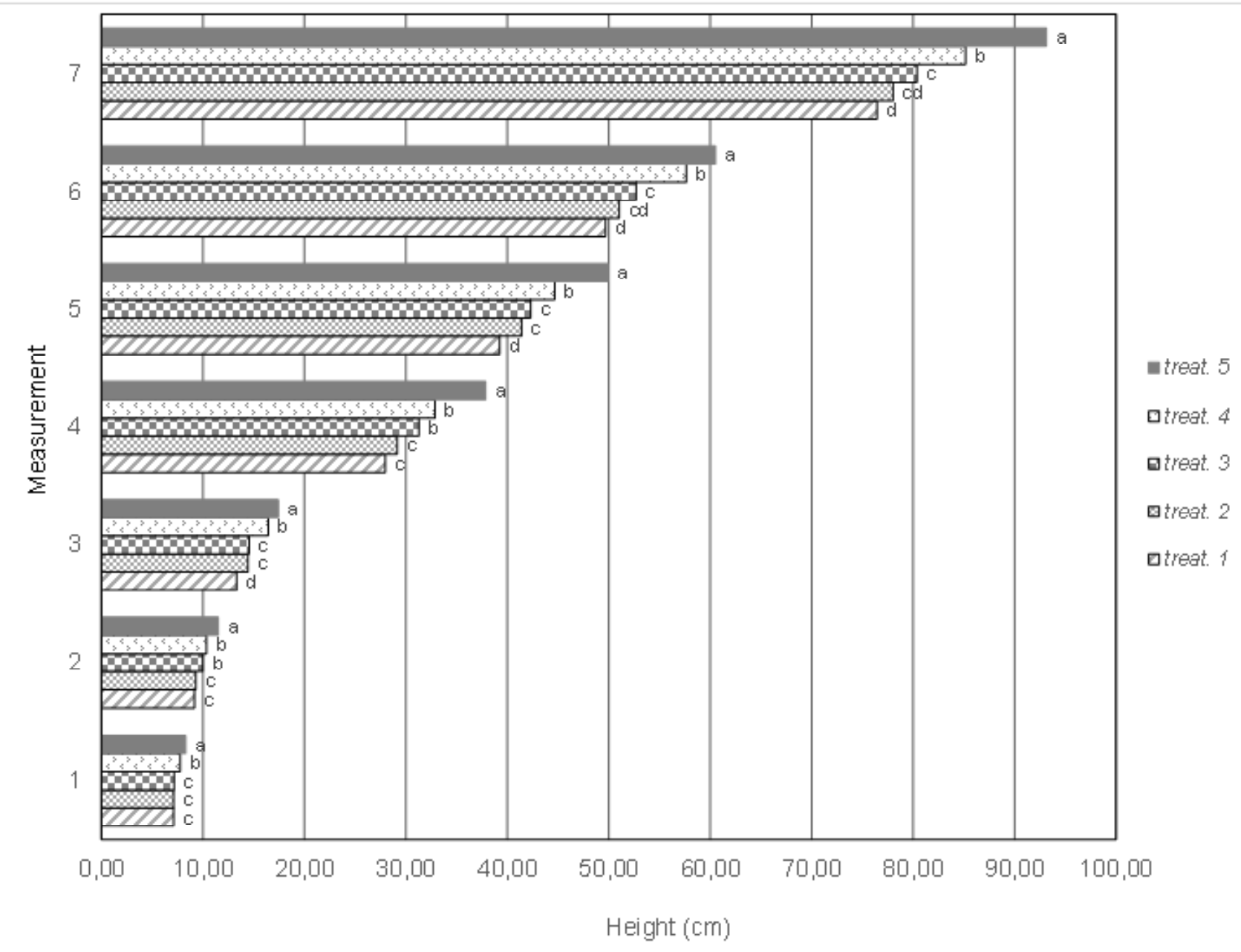

Fig. 7: The average hight of the plants carried out for each treatment. Means followed by different letter within a treatment significantly differ $(\mathrm{LSD}, \mathrm{p} \leq \mathbf{0 . 0 5})$.

treatments 2 and 3. Consequently, the average difference in height between the lowest plants in treatment $1(76.5 \mathrm{~cm})$ and highest plants in treatment $5(93.2 \mathrm{~cm})$ was almost $17 \mathrm{~cm}$.

At cutting time, stage of development of most of the plants was associated with the appearance of the first flowers (10 $\%$ blooms) or half bloom (50\%). In all treatments, lucerne achieved the height which some authors indicated as preferred time for the first mowing. Chen et al. (2012) and Ernert (2014) recommended the first mowing at the plant height of 50 to $70 \mathrm{~cm}$, due to the favourable relationship between yield and crude protein content. Hakl et al. (2010) reported very similar plant height $(75$ to $80 \mathrm{~cm})$ as the appropriate time for the first mowing of lucerne. However, the optimal harvesting time in this case was associated with the development stages buds and first flowers, because, in the later development stages, digestibility of lucerne fodder is drastically reduced (Meyer 2005).

\section{CONCLUSIONS}

The obtained results highlight the complexity of the problem:

- The highest dry matter yields of last autumn harvesting of lucerne were achieved if mowing had taken place 53 to 46 days after the previous harvesting. This means that plants reached optimal development stage suitable for cutting (beginning of flowering).

- Time of the last autumn cutting of lucerne did not significantly affect the DMY of the first mowing in the following year. However, CPY, NELY, MEY and lucerne height significantly differed among treatments. The highest measured and calculated value of all parameters was achieved when the last autumn harvesting had taken place 66 to 73 days before the first frost. Values of DMY, CPY, and NELY, MEY as well as the plant height of the first mowing in the next year were lower if the autumn cutting had taken place earlier.

- The time of the last autumn harvesting did not significantly affect the content of CP and the calculated values of NEL and ME in plant samples of the first cut in the next year. However, significant differences of the CPY, NELY and MEY were mainly due to differences in DMY. 


\section{REFERENCES}

1. Agrometeorological portal of Slovenia. [online], 2015. date: 10/September/2015 (website: http://agromet.mko. gov.si/APP/Detail/METEO/120)

2. Barnes DK and Sheaffer CC. Alfalfa. In: Barnes RF, Miller DA and Nelson CJ. (eds) Forages, 5th edn. Vol. 1, An Introduction to Grassland Agriculture. Iowa State University Press, Ames, Iowa, 1995; 205-216.

3. Chen J, Tang F, Zhu R, Gao C, Di G and Zhang Y. Effects of cutting frequency on alfalfa yield and yield components in Songnen Plain, Northeast China. Afr. j. biotechnol. 2012; 11(21): 4782-4790.

4. Ernert S. Anbauanleitung Luzerne. [online], 2014. date: 15/September/2015 (website: http://www.pflanzenbau. rlp.de/Internet/global/themen.nsf/cb2900a7cef96297c1 25727b00431e27/a7732e1b974eeb9cc1257a3f003baa19? OpenDocument)

5. Frame J, Charlton JFL and Laidlaw AS. Temperate Forage Legumes. CAB International, Wallingford, New York, US, 1998.

6. Genever L and McConnell D. Growing and Feeding Lucerne. Agriculture and Horticulture Development Board, 2014; 1-20.

7. GfE. Neue Gleichungen zur Schätzung der Umsetzbaren Energie für Wiederkäuer von Gras- un Maisprodukten. Proc. Soc. Nutr. Physiol. 2008; 17: 191-198.

8. Hakl J, Šantrůček J, Fuksa P and Krajíc L. The use of indirect methods for the prediction of lucerne quality in the first cut under the conditions of Central Europe. Czech J. Anim. Sci. 2010; 55: 258-265.

9. Heichel GH and Henjum KI. Dinitrogen fixation, nitrogen transfer and productivity of forage legume-grass communities. Crop Sci. 1991; 31: 202-208.

10. Katić S. Značaj jesenje kosidbe za uspešno prezimljavanje lucerke. Zavod za krmno bilje, Institut za ratarstvo i povrtarstvo. [online], 2003. date: 22/October/2015 (website: http://poljoprivreda.info/?oid=2\&id=244)

11. Katić S, Mihailović V, Milić D, Vasiljević S and Karagić Đ. Uticaj učestalosti košenja na prinos i trajnost polusrodnih porodica lucerke. Zbornik radova, Institut za ratarstvo I povrtarstvo, Novi Sad, 2007; 44: 21-28.

12. Kendall WA, Shaffer JA and Hill RR. Effect of temperature and water variables on the juvenile growth of lucerne and red clover. Grass forage sci. 1994; 49: 264-269.

13. Korošec J. Pridelovanje krme na travinju in njivah. Ljubljana, Biotehniška fakulteta, Oddelek za agronomijo, 1998; 180-189.

14. Kramberger B. Pridelovanje krme. Maribor, Visoka kmetijska šola, 1995; 76-80, 126-132.

15. Major DJ, Hanna MR and Beasley BW. Photoperiod response characteristics of alfalfa (Medicago sativa L.) cultivars. Can. J. Plant Sci. 1991; 71: 87-93.

16. Međimurec T. Lucerna-kraljica krmnih kultura. Savjetodavna služba. [online], 2007. date: 11/September/2015 (website: http://www.savjetodavna.hr/savjeti/13/109/ lucerna-kraljica-krmnih-kultura/)

17. Meyer DW. Plant height as determinant for harvesting alfalfa. In: Forage Focus, Meyer D.W. (Ed.). Midwest Forage Association, Minneapolis, USA, 2005; 12-13.
18. National Meteorological Service. RS Ministrstvo za okolje in prostor, ARSO. [online], 2015. date: 9/September/2015 (website: http://meteo.arso.gov.si/uploads/probase/www/ climate/table/sl/by_location/rogaska-slatina/climatenormals_81-10_Rogaska-Slatina.pdf)

19. Sheaffer CC, Wiersma JV, Warnes DD, Rabas DL, Luesche WE and Ford JH. Fall Harvesting and Alfalfa yield, persistence and quality. Can. J. Plant Sci. 1986; 66(2): 329338.

20. Small E. Alfalfa and Relatives: Evolution and Classification of Medicago. CAB International, Cambridge, UK, 2011.

21. Statgraphics ${ }^{\oplus}$ (Release Centurion XV) StatPoint, Inc., 2005.

22. Statistical Office of the Republic of Slovenia. [online], 2015. date: 8/September/2015 (website: http://pxweb.stat. si/pxweb/dialog/Saveshow.asp)

23. Steinhöfel O and Hoffmann M. Handbuch Grobfutter. AVA, Horstmar-Leer, Germany, 2013.

24. Witty JF, Minchin FR and Sheehy JE. Carbon costs of nitrogenase activity in legume root nodules determined using acetylene and oxygen. J. exp. bot. 1983; 34: 951-963. 


\section{Vpliv pozne jesenske košnje lucerne (Medicago sativa L.) na ritem rasti prve košnje $v$ naslednjem letu}

\section{IZVLEČEK}

V poljskem mikroposkusu, v Spodnjem Gaberniku (n.v. $258 \mathrm{~m}, 46^{\circ} 15^{\prime} 54.94^{\prime \prime} \mathrm{N}$ in 15³4'6.05" E), smo v četrtem letu rasti lucerne (Medicago sativa L.) sorte 'Soča', ugotavljali vpliv zadnje jesenske košnje na razvoj in kakovost pridelka prve košnje v naslednjem letu. Poskus je bil zasnovan po metodi naključnega bloka v štirih ponovitvah. Posamezno obravnavanje (1) 24.9.2014, (2) 01.10.2014, (3) 08.10.2014, (4) 15.10.2014 in (5) 22.10.2014) so predstavljali tedenski zamiki jesenske košnje. V prispevku so podani rezultati pridelka suhe snovi (SS) po obravnavanjih $\mathrm{v}$ primerjavi s prvim odkosom $\mathrm{v}$ letu 2015 (18.05.2015). Pred košnjo v letu 2015 smo na osnovi meritev višine rastlin spremljali razvoj lucerne v posameznem obravnavanju. Kakovost pridelka smo ovrednotili z NIRS metodo. V odvzetih suhih vzorcih smo določili vsebnost surovih beljakovin (SB) in izračunali NEL in ME v rastlinskih vzorcih. Statistično značilno najvišje pridelke SS smo v jeseni 2014 dosegli v obravnavanjih košenih najkasneje (5 in 4). Prav tako v letu 2015 ugotavljamo trend višjih pridelkov SS pri kasneje košenih obravnavanjih jeseni 2014. Statistično značilne razlike smo ugotovili pri hektarskih pridelkih SB, NEL in ME. Pri merjenju višine posameznih rastlin pred prvo košnjo spomladi 2015 je bil opazen statistično značilen trend višjih rastlin $\mathrm{z}$ opravljeno poznejšo zadnjo košnjo v letu 2014.

Ključne besede: lucerna, Medicago sativa, čas košnje, ritem rasti in razvoja, pridelek 